\title{
'Keep your face out of my way or l'll bite off your nose': homoplastics, sympathy, and the noble body in the Tatler, 1710
}

Article

Accepted Version

Skuse, A. (2017) 'Keep your face out of my way or l'll bite off your nose': homoplastics, sympathy, and the noble body in the Tatler, 1710. Journal of Early Modern Cultural Studies, 17 (4). pp. 113-132. ISSN 1553-3786 doi:

https://doi.org/10.1353/jem.2017.0028 Available at https://centaur.reading.ac.uk/69991/

It is advisable to refer to the publisher's version if you intend to cite from the work. See Guidance on citing.

To link to this article DOI: http://dx.doi.org/10.1353/jem.2017.0028

Publisher: University of Pennsylvania Press

All outputs in CentAUR are protected by Intellectual Property Rights law, including copyright law. Copyright and IPR is retained by the creators or other copyright holders. Terms and conditions for use of this material are defined in the End User Agreement.

www.reading.ac.uk/centaur 
Central Archive at the University of Reading

Reading's research outputs online 


\title{
'Keep your face out of my way or I'll bite off your nose'
}

Homoplastics, Sympathy, and the Noble Body in The Tatler, 1710

\section{ALANNA SKUSE}

\begin{abstract}
This essay discusses Joseph Addison's 1710 satiric article 'Noses' as a fantasy of bodily alteration which responded to scientific and cultural developments of the previous hundred years. It shows how the piece draws upon and expands the 'nose reconstruction' operation detailed in Gaspare Tagliacozzi's 1597 De Curtorum Chirurgia. Over the course of the seventeenth century, this operation became associated with the practice of allography, grafting parts from one individual of a particular species onto another. This association was augmented by scientific experiments and theories including blood transfusion, dissection, and the doctrine of sympathy. In Addison's satire, the notion of a new nose made from the flesh of another person becomes a vehicle for wider questions about the meaning of bodily identity, and social status indexed to that identity, in the face of new medical possibilities.
\end{abstract}

The impulses of the mind ... affect the body so profoundly that one can hardly doubt but that the unknown can be revealed by the known and the hidden by the conspicuous; that is, the very nature of the mind can be revealed by the lineaments of the body. (Tagliacozzi 12)

Writing on the importance of the face in his 1597 De Curtorum Chirurgia per Institionem, Gaspare Tagliacozzi knew that the body was never just a body. Inscribed with political, social, moral and spiritual significance, the flesh - and particularly the face - revealed the 
"unknown" and "hidden" parts of the person to whom it belonged. What happened, then, when one's face was not entirely one's own?

This article explores the implications of a peculiar bodily alteration in an era in which physicality was indexed to social status. It will show how early modern satirists and physicians reimagined the famous nose-reconstruction operation of Tagliacozzi, the 'father of plastic surgery'. In the light of mid-seventeenth-century scientific experimentation, I will argue that Tagliacozzi's experiments were readily construed as homoplastic procedures, taking skin from one person to craft a new nose for another. Finally, I will read Joseph Addison's 'Noses' essay of 1710 as a fantasy of homoplastic surgery, which highlights the difficulty of aligning physiological and social attributes in an era that increasingly destabilised the connection between body and 'self'.

My reading is premised on the idea that the noble body was a constituent of nobility, such that nobility might even be said to inhere in the flesh of the aristocrat. This idea has in recent years been persuasively advanced by scholars of the medieval period, early modern period and the eighteenth century, and has facilitated investigations into death, masculinity, sexuality and race among other topics. ${ }^{i}$ As Alexandra Shepard has shown, it was held in the sixteenth and seventeenth centuries that virtues such as chivalry, honesty and bravery could be found 'in' the nobility in a physiological sense. Indeed, "aspirations to the temperate [bodily] ideal were restricted to an elite minority variously distinguished by their moral, religious, and, more implicitly, their social superiority" (49). Furthermore, the fast-changing economic climate of the early modern period both undermined and rendered sacrosanct the connection of bodily qualities with social standing. As Mark Breitenberg has observed, "the term 'aristocratic body' denotes not a readily distinguishable rank in early modern England ... but rather an ideal to which various degrees of the gentry might aspire, or a symbol that might legitimate newly acquired status as if it were inherent." (73). That is, when somebody 
from a non-noble family became wealthy, a gap opened between economic status and more traditionally determined 'rank'. In such circumstances, the body might close the gap and legitimate the possessor, or it might continue to belie their humble origins. Moreover, the noble body was a particularly important feature of the male aristocrat, whose seed was commonly understood as that which shaped the gross matter supplied by females in the generative process (see Cobb [especially 210-20] and Crawford, 'Sexual Knowledge').

While seductive, however, notions of the naturalness of noble bodies were not uncomplicated. Many physical assessments of nobility were more or less founded on physiognomy, the notion that character could be read in a person's facial features. Physiognomy had a long history, reaching back to Greek classicism, and bolstered by the Galenic notion that bodily temperature might govern characterological temperament $(\mathrm{R}$. Porter 245-6). Moreover, it placed particular importance on the nose, the size and shape of which was believed to denote personal qualities including "straitnesse of heart and indignation of thought" (Vicary 37). In privileging this organ, physiognomists shared something with more informal, but long-standing adages about the significance of the nose. In the popular imagination, the size of a man's nose might correspond with that of his penis, while, as Peter Berek has shown, comedically oversized noses were often used to denote Jewishness on the early modern stage (Walker 92; Berek 55-70). The mutilated, slit or amputated nose, meanwhile, was "situated within the idiom of insult," marking out the bearer as deceitful, roguish or seditious, and being closely associated with castration (Walker, 92). With this mixture of credibility and scurrility, physiognomy proved immensely popular for much of the early modern period; Martin Porter estimates that there were somewhere around 300,000 copies of texts on physiognomy circulating in England during 1470-1780 (M. Porter 96). Nonetheless, physiognomy seemed to lose much of its authority in the early eighteenth century, shifting from a fairly respectable branch of natural philosophy to a "vulgarised" 
parlour game (though later to be revived by Lavater's 1775 work on the subject). The reasons for this shift were manifold, and are discussed at length in Martin Porter's Windows of the Soul: Physiognomy in European Culture 1470-1780 (2005). Among the chief factors, however, was a rise in the use of cosmetics, which accompanied an increasing emphasis on fashion and self-fashioning of the body (R. Porter, especially 244-57). As Roy Porter points out, this necessarily undermined the "universal sign-grammar of good and bad" (246) promised by physiognomic reading:

It had always been acknowledged, of course, that reading character might present difficulties, rather like peering through a glass darkly; but what if looks were actually designed to lie? How could physiognomy cope with systematic hypocrisy of countenance? (R. Porter 251)

From a literary perspective, Barbara M. Benedict identifies the decline of physiognomy as linked with the rise of rationalism, and of forms of reading, such as novels and newspapers, which emphasised personal inquiry (Benedict 314). Early eighteenth-century writing, she argues, became more interested in people's actions, and the social contexts that drove them, than in innate qualities. ${ }^{\text {ii }}$

Both these factors - the rise of cosmetics and the consumption of rationalist literature - may be viewed as aspects of an incomplete but nonetheless significant shift in attitudes toward nobility itself. It is evident that, following the civil wars in the mid-seventeenth century and then the Glorious Revolution in 1688 , the absolute authority of the monarch and in particular, their divine right to rule - was much weakened. Accordingly, the top-down system of aristocracy, based firmly on bloodline, could no longer be assumed to be the 'natural' order. Michael McKeon identifies “mounting scepticism about the purity of aristocratic blood", epitomised by Daniel Defoe's ridicule of the very idea that honour might be biologically inherited (154). Meanwhile, Lawrence Stone describes the emergence in this 
climate of a "squirarchy"; still constituted of the "landed elite", but with strong connections with the wealthy bourgeoisie (175). Among this squirarchy, he argues, was fostered a new sense of individualism, personal development and the pursuit of personal happiness as the highest good (173-6). While opinion about the extent of social change in the seventeenth and eighteenth centuries remains divided, it is clear that the body and its qualities remained central in debates about the right of one individual to assert moral and social superiority over another.

\section{New Noses for Old}

In a broad sense, assuming materials from another human body was not particularly unusual during the early modern period. A thriving tradition of medicinal cannibalism, as detailed by Louise Noble, saw the ingestion of 'mummy' made from desiccated corpses; less grisly remedies included breast milk and urine (Noble, Medicinal Cannibalism; Paster 192). More superficially, wigs were routinely made from human hair (including, famously, Charles II's wig made from the pubic hair of his mistress) (Rosenthal 1). Recent scholarship on prostheses - in particular, Will Fisher's Materializing Gender - has also emphasised the extent to which bodily accoutrements from beards to handkerchiefs may be viewed as "detachable parts" which "quite literally reformed or reconstituted" the body (24). Here, however, I am particularly interested in human materials which were added or substituted onto another human body in such a way that they could not easily be removed, and might readily be perceived as intrinsic to oneself. I use the anachronistic but nonetheless useful terms 'allograft' and 'homoplastic' to describe such materials and procedures. ${ }^{\text {iii }}$ The principal objects of homoplastic procedures were human teeth, and there is evidence of tooth transplants having taken place throughout the early modern period. Indeed, John Woodforde describes the procedure as having become a "craze" in the eighteenth century, despite the operation's varied results and the occasional qualms of surgeons about thus "robbing Peter to 
pay Paul" (81; see also Allen 13). However, this operation lacked the drama of nosereconstruction, with its lengthy, dangerous stages and dramatic results. As I shall discuss, despite the fact that Tagliacozzi never advocated using allografts in his nose reconstruction operation, it was in this context that early modern medical professionals and lay people most readily and vividly imagined a human-to-human graft.

In one form or another, nose reconstruction surgery seems to have been a fixture of the medical profession for over 2000 years. In their comprehensive The Life and Times of Gaspare Tagliacozzi, Jerome Webster and Martha Teach Gnudi find nose reconstruction operations, including skin grafts taken from the cheek, to have been first detailed in the ancient Hindu surgical writings of Susrata (106). Though its history thereafter is murky, at some point, probably by the tenth century $\mathrm{AD}$, this text's secrets travelled westward, to the Mediterranean (ibid, 107-8). The first detailed account of the nose-reconstruction operation being practiced in Europe comes from the fifteenth-century Italian historian Bartholommeo Fazio, describing the work of father-and-son surgeons Branca the Elder and Antonio Branca (ibid, 110). In the sixteenth century, Tagliacozzi is believed to have learned his craft from the Brancas, becoming renowned for his ability to craft a nose "so resembling nature's pattern, so perfect in every respect that it was [the patients'] considered opinion that they like these better than the original ones which they had received from nature" (Tagliacozzi, 'Letter to Hieronymus Mercurialis').

Tagliacozzi's painstakingly detailed instructions for this operation in De Curtorum suggest that he had undertaken the procedure many times, despite the fact that this appears to have been a long, risky and painful process. To craft the new nose, a portion of the skin of the arm first had to be lifted up with forceps and cut on two sides, before lint was placed underneath to prevent the skin reuniting with the flesh (133-5). When the swelling from this wound had died down, one was to cut the third edge of the skin flap, fold it backwards, and 
bandage it (150-7). After two weeks or so, one could consider suturing the flap - still attached at one end to the arm - to the mutilated nose, binding the area with specially made bandages (170-7). For the first week, it was essential that the patient avoid any movement, even talking, if the skin was to have a chance of adhering. Three weeks later, one might fully detach the skin from the arm and continue shaping the nose. However, it would be a further six to nine weeks before the surgeon could form the nose's columella, and two more weeks before the nostrils could be formed (200-2). Even Tagliacozzi was under no illusions about the palatability of his operation. Though he claimed a high success rate, the text is full of precautions about the pitfalls of every stage, and he recalls that during the engrafting process: The blood flows so freely ... that it impairs the physician's vision, often causing delays, and if the physician is at all inattentive, he will not be able to avoid error. The patient, wracked with pain, often attempts to ward off the knife, thus destroying the surgeon's chances of preparing the nose properly and uniting it with the graft in a seemly and harmonious way ... There is, after all, an obvious difference between simply uniting the parts and joining them gracefully and symmetrically ... Even a superficial examination of this topic shows that Nature can provide examples of how to shape the nose, while the engrafting process is in the hands of the physician alone. He uses only his intellect, instinct, and skilled hands and does not have any example to imitate, save that which he holds in his mind. (De Curtorum 170)

Partly because of the difficulties Tagliacozzi described, and partly because of misinterpretations and corruptions of his instructions, it has been widely believed that his operation fell out of favour in the later sixteenth century, leaving plastic surgery to stagnate until the First World War revived the craft (Cock, “"LL]eading 'em by the nose”"). However, Emily Cock's recent work on the topic has convincingly repudiated this assumption, highlighting the positive presentation of, and comprehensive instructions for, nose 
reconstruction in Alexander Read's 1687 Chirurgorum Comes (a text which, as Cock notes, remains under-studied) (““[L]eading "em by the nose"”). It is unclear if Read or his contemporaries actually carried out the operation described in this text. What both Cock and Webster and Gnudi have made clear, however, is that public and medical interest in the nose reconstruction operation continued unabated throughout the seventeenth century (Cock, 8-12; Webster and Gnudi, 273-80, 303-7). It is also evident that in many cases, this interest was piqued by the folkloric belief that the operator might take the skin or flesh of another human to supply the graft material for nose reconstruction. This imputation was undoubtedly rather unfair, since there is no evidence that Tagliacozzi ever took tissue from one person to apply to another. Indeed, as Webster and Gnudi identify, he explicitly advised against such an undertaking in the Curtorum, cautioning that:

If the physician attempted to take the graft from a person other than the patient, the outcome would surely be imperilled ... Would two people ever consent to being bound together so intimately and for so long? I certainly cannot imagine it ... How difficult it would be for the parties involved to eat, sleep, stand, or perform any other necessary actions! I doubt that anyone will deny the inconvenience and impracticability of this idea; the danger to the patient would be considerable and the outcome dubious, if not hopeless. (76-7)

Nonetheless, rumours of wealthy and squeamish patients taking skin from the arm of a slave or servant in order to fashion a new nose proved remarkably persistent (so persistent, in fact, that one suspects at least one surgeon must have ventured to try a nasal allograft). As early as 1503 - long before Tagliacozzi, when the nose reconstruction operation was being carried out by Branca the Elder - one letter-writer reported that the nose could be supplied from the arm or 'borrowed' from a slave (Gnudi and Webster, 109). That account was made widely accessible by inclusion in Etienne Gourmelon's 1580 Chirurgicae Artis (ibid, 112). 
Seventeenth-century reports of homoplastic nose grafts developed this idea, and commonly included some aspect of sympathetic connection between the grafted nose and its original 'owner'. Jean-Baptiste van Helmont, for instance, attested that

A certain inhabitant of Bruxels, in a combat had his nose mowed off, addressed himself to Tagliacozzus a famous Chirurgeon ... that he might procure a new one; and when he feared the incision of his own arm, he hired a Porter to admit it, out of whose arm, having first given the reward agreed upon, at length he dig'd a new nose. About thirteen months after his return to his own Countrey, on a sudden the ingrafted nose grew cold, putrified, and within a few days, dropt off. To those of his friends, that were curious in the exploration of the cause of this unexpected misfortune, it was discovered, that the Porter expired, neer about the same punctilio of time, wherein the nose grew frigid and cadaverous. (13-14)

In 1662, James Cooke's Mellificum Chirurgiae provided readers with a brief description of the operation, adding that the grafted tissue "may be either from their own bodies or some others: if they choose anothers [sic], let them be sure they are longer lived than themselves, lest they lose their Nose again before they die" (374). Thirty-seven years later, M. de la Vauguion was more circumspect about accusing Tagliacozzi of homoplastic surgeries, but readily attested that "the Ancients repaired the loss of parts, as a Nose cut off or the like, by inoculating Flesh out of the Arms or Buttocks of their Slaves" (355).

When Samuel Butler and Joseph Addison satirised the allograft nose, their seriocomic works would draw upon the over-earnest reports of concerned medical practitioners such as Cooke and Helmont. Nonetheless, both satirical and earnest accounts of the operation interacted with some of the most potent anxieties and fantasies in contemporary scientific thought. In the 1660 s, members of the Royal Society were actively engaged in testing the boundaries of bodily integrity. Experimenting on dogs, they embarked on a series of trials, 
making blood transfusions between one animal and another, removing organs, making skin grafts, and on one occasion keeping a dog alive by inflating its lungs with bellows whilst they inspected the animal's beating heart (Hamilton, 25-6; Guerrini, 'The Ethics of Animal Experimentation'). Moreover, some experiments tested the boundaries between one species and another. In 1667-8, blood transfusions between animals and humans were undertaken in France and England, and were eagerly documented in the Royal Society's Philosophical Transactions. The procedure's pioneer, Jean-Baptiste Denis, claimed to have cured several patients of intractable illness and madness by infusing them with lamb's or calf's blood, and in 1667, Edmund King and some colleagues transfused blood from a sheep to a clergyman (Turner, 163-70; Guerrini, 404). Such events invited speculation on the possible transfer of characteristics and behaviour between the subjects. Writing on dog-to-dog transfusions in 1666, for instance, Robert Boyle pondered

Whether by this way of Transfusing Blood, the disposition of individual Animals of the same kind, may not be much altered (As whether a fierce Dog, by being often quite new stocked with the blood of a cowardly Dog, may not become more tame; \& vice versa, \&c.?) (Philosophical Transactions no. 22, 385)

Though Cock correctly asserts that " $[\mathrm{t}]$ here is no association made with Tagliacozzi in discussions about [experimental] transplants", it seems likely that such experimentation contributed to a cultural milieu in which homoplastic surgery on humans appeared possible and even likely (20).

The early modern period also saw the popularisation of the doctrine of sympathy, particularly in medical contexts. Influenced by Paracelsus and Van Helmont, adherents to this doctrine contended that all bodies shared a connection with one another, either mystically or (in later iterations of the doctrine) via material qualities (Lobis 9-13). Moreover, while Michel Foucault may have influentially argued for the obsolescence of this worldview after 
the Restoration, recent work by Seth Lobis has convincingly demonstrated that sympathy remained a topic of discussion throughout the seventeenth and into the eighteenth centuries, being reworked into new forms rather than wholly rejected. Among the most influential writers on sympathy were Sir Kenelm Digby and Robert Fludd, both of whom defended the idea of curing by sympathy, with "sympatheticall powder" and "weapon-salve" respectively (Digby, A Late Discourse; Fludd, Doctor Fludds Answer). By exploiting the sympathetic connection between a weapon and the wound it had created, or between a drop of blood and the whole body, the authors asserted that even serious injuries might be cured without ever seeing, much less touching, the patient (Lobis, 45-50). ${ }^{\text {iv }}$

Furthermore, Fludd and Digby explicitly linked the mysterious properties of the allograft nose to sympathetic doctrine. Fludd, for instance, told the story of an Italian nobleman who had, after losing his nose, persuaded his slave to provide the flesh needed to make another. Afterwards, he reported,

The slave being healed and rewarded, was manumitted, or set at liberty, and away he went to Naples. It happened, that the slave fell sicke and dyed, at which instant, the Lords nose did gangrenate and rot; whereupon, the part of the nose which hee had of the dead man, was by the Doctors advice cut away. (132)

Fludd insisted that this phenomenon should be attributed not to the "trumpery of the divell" but rather "God's vivifying spirit," which operated so remarkably that despite the distance between the nose's original owner and its new possessor, "neither the tall Hills of Hetruria; nor yet the tall Appenine mountaines could stop the concourse and motion of these two spirits, or rather one spirit continuated in two bodies" (133). While approaching the subject more tentatively, Digby likewise posited that "artificiall noses that are made of the flesh of other men ... do putrifie as soon as those persons out of whose substance they were taken 
come to die, as if that small parcell of flesh inngrafted upon the face did live by the spirits it drew from its first root, and source" (115-6).

This doctrine's bold claims made it an easy target for detractors. In a refutation of Fludd's work, William Foster represented sympathetic cures as witchcraft, "done by the helpe of the divell the corrupter of nature" (Foster, Hoplocrisma Spongus 3). Furthermore, the notion of animating "spirits" intrinsic to matter was clearly difficult to reconcile with traditional ideas of the soul as an indivisible entity (ibid, 27-8). Though Fludd's work on weapon salve was published shortly before the birth of John Locke, it seems clear that some parts of the later debate around materiality and human identity may have been rehearsed in arguments about sympathy. As the seventeenth century wore on, the doctrine waned in popularity, and "discussions of sympathetic cures came to center less on how they worked, and more on if they worked at all" (Lobis 37). Like physiognomy, however, the turn away from sympathy may have been one of "varied reconception rather than thoroughgoing rejection" (Lobis 19). While the notion of inanimate matter possessing sympathetic properties was being rejected at around the time of Addison's writing, natural philosophers such as George Cheyne and Robert Whytt would later argue for the existence of an intrapersonal variety of sympathy which was closely related to nervous sensibility (Mullan 228-30. As John Brewer discusses, "The precise physiology of this phenomenon [sensibility] was a source of considerable dispute ... more important was the growing consensus that the feeling body consisted of a series or organs which were connected to one another by their collective sympathy to one another" (24). In 1765, Whytt asserted that "we know certainly, that the nerves are endued with feeling, and that there is a general sympathy which prevails through the whole system; so there is a particular and very remarkable consent between various parts of the body" (Whytt v-vi). Though less radical than those of Digby and Fludd, such theories continued to emphasise the mysterious properties of flesh. Furthermore, they invited many of 
the same questions about the possibility of allography; could attached flesh ever 'sympathize' with one's native organs?

\section{'Fashionable Cripples'}

When Joseph Addison began his essay on 'Noses' for issue 260 of Tatler magazine, he thus did so against a backdrop of over 50 years of interest in the limits of the individual body, and nearly two centuries of debate about nose transplantation. Inevitably, Addison framed his essay as a 'dissertation' upon the preeminent satire of the Tagliacotian operation, Samuel Butler's Hudibras:

So learned Talicotius from

The brawny part of Porter's bum

Cut supplemental noses, which

Lasted as long as parent breech:

But when the date of nock was out,

Off drop'd the sympathetic snout.

Aligning himself firmly with Hudibras's mock-heroism, Addison gives a mannered account of "a little burlesque poem in Italian" explaining "the rise of that fatal distemper which has always taken a particular pleasure in venting its spight upon the nose" (244). He then launches into a clearly fictionalised but nonetheless incisive account of Tagliacozzi's practice as the greatest "clap-doctor" of his age, which is worth citing at length:

His first patient was a great man of Portugal, who had done good services to his country, but in the midst of them unfortunately lost his nose. Talicotius grafted a new one on the remaining part of the gristle or cartilaginous substance, which would sneeze, smell, take snuff, pronounce the letters $\mathrm{M}$ or $\mathrm{N}$, and in short, do all the functions of a genuine and natural nose. There was however one misfortune in this experiment. The Portuguese's complexion was a little upon the subfusc, with very 
black eyes and dark eyebrows, and the nose being taken from a porter that had a white German skin, and cut out of those parts that are not exposed to the sun, it was very visible that the features of his face were not fellows. In a word, the Conde resembled one of those maimed antique statues that has often a modern nose of fresh marble glewed to a face of such a yellow ivory complexion as nothing can give but age. To remedy this particular for the future, the doctor got together a great collection of porters, men of all complexions, black, brown, fair, dark, sallow, pale, and ruddy; so that it was impossible for a patient of the most out-of-the-way colour not to find a nose to match it.

The doctor's house was now very much enlarged, and become a kind of college, or rather hospital, for the fashionable cripples of both sexes that resorted to him from all parts of Europe [...] It is reported, that Talicotius had at one time in his house twelve German counts, nineteen French marquisses, and a hundred Spanish cavaliers, besides one solitary English esquire, of whom more hereafter. Though the doctor had the monopoly of noses in his own hands, he is said not to have been unreasonable. Indeed if a man had occasion for a high Roman nose, he must go to the price of it. A carbuncle nose likewise bore an excessive rate: but for your ordinary short turned-up noses, of which there was the greatest consumption, they cost little or nothing; at least the purchasers thought so, who would have been content to have paid much dearer for them, rather than to have gone without them. (244-5)

This extraordinary account defies categorisation according to the terms of recent works on pox literature. Betty Rizzo argues that eighteenth-century writings, particularly periodicals, took a relaxed approach to the problem of venereal disease, conflating syphilis with the less serious complaint of gonorrhoea, and presenting both as scars attained in the "wars of love" (154). Certainly, Addison's high burlesque tone makes this a comical essay. 
His evocation of the noble Roman statue made ridiculous by its poorly matched nose is a particularly well-aimed jibe at those would-be gallants who now sport noses fashioned "of those parts that are not exposed to the sun" (that is, the buttocks). That Addison chose the example of Roman statues in particular was no accident. The violation of decorum and proportion in the Tagliacotian operation was thus abruptly juxtaposed with the neoclassical virtues exemplified in Greco-Roman art.

Tagliacozzi's alleged collection of patients, however, gestures toward a more serious problem than cosmetic mismatching. While Addison may frame the "fatal distemper" in light-hearted terms, the roster of foreign sufferers underlines the long-standing association between venereal disease and disorderly foreign habits. The multitude of Spanish cavaliers is particularly telling. Those who recommended the nose reconstruction operation, including Tagliacozzi, presented it as a remedy for soldiers, who were likely to have been mutilated in battle. Despite its joviality, Addison's story dispels that notion, and instead points directly to the complaint's real cause, sexual incontinence. In doing so, it reveals a more censorious stance in which pox might be seen not as a rakish mark of honour but, as Rose Zimbardo asserts, "empirical evidence of the personal immorality and social/political degeneracy of a marginalized 'other'” (184).

From this perspective, the sheer numbers of infected patients imagined in Addison's essay imply some rather sinister possibilities to the nose-maker's work. If one could, as Addison imagined, create a nose which perfectly matched the recipient, then the infected person's status might become invisible to others, including potential sexual partners. Writing on the uses of cosmetics in the early modern period, Farah Karim-Cooper observes that make-up and prosthetics were popularly associated with "moral corruption and feminine deception", seeking to improve on God's handiwork and to ensnare men under false 
pretences (2). This was not only a moral but a socio-economic issue, as made clear in John Gauden's 1656 Discourse of Auxiliary Beauty:

the wise Creator hath by nature impressed on every face of man and woman, such Characters, either of beauty, or Majesty, or at least of distinction, as he sees sufficient for his own honor, our content, and others sociall discerning or difference, whereby to avoyd confusions or mistakes. (34)

Furthermore, Gauden argued at length (albeit ultimately in defence of cosmetics) that there was no difference between women who used cosmetics and people of either sex who used prostheses, including false noses $(43-5,59-60)$. William H. Kerwin also identifies this anxiety in relation to the Renaissance surgeon. Despite ostensibly opening up the body, he notes, surgeons frequently functioned as "managers of exterior appearances and keepers of secrets about the gap between outer order and inner disorder" (98).

The role of cosmetics and prosthetics is not, however, simply to restore the body. As Karim-Cooper recognizes, and as I shall discuss, a growing body of critical literature has recently highlighted the status of the prosthetic - in broad terms - as a 'supplement' which highlights deficiency in the same moment as it attempts to obfuscate it. In Addison's essay, this phenomenon renders the noble body vulnerable to adulteration. It is notable that Addison's skin-donors, following Hudibras's example, are all porters - men of lowly status, offering skin from the lowliest part of their anatomy. This class differential is apparent in all stories of nose reconstruction by allograft, and unsurprisingly so. One would need to be under considerable duress, or receive a significant financial reward, in order to agree to the pain and inconvenience the procedure involved. Nonetheless, such a graft also serves the satiric purpose of creating a relationship between donor and recipient that is (literally and figuratively) too close for comfort. The recipient of the allograft - in each case, a member of the 'better sort', though not necessarily of the elite - relies on their lowly donor. Moreover, 
reconstructive surgeries at this time relied on living (as opposed to free) skin grafts. The counts, cavaliers and others described by Addison would have had to attach their face directly to the porter's buttocks for anywhere between five and forty days.

The debasement involved in this procedure is self-evident. Moreover, the engrafted nose serves, in Addison's account, as a constant reminder of that debasement. The noble and ignoble body would be indelibly linked, and not only in the recipient's memory. Expanding on the popular idea of the engrafted nose dropping off with the death of the original 'owner', Addison asserts:

The sympathy betwixt the nose and its parent was very extraordinary. Hudibras has told us, that when the porter died, the nose dropped of course, in which case it was always usual to return the nose, in order to have it interred with its first owner. (246) The interment of the nose makes clear that the recipient's new appearance is not true reparation but a palimpsest; morally and spiritually, the nose remains a 'part' of the porter's body. Moreover,

The nose was likewise affected by the pain as well as death of the original proprietor. An eminent instance of this nature happened to three Spaniards, whose noses were all made out of the same piece of brawn. They found them one day shoot and swell extremely, upon which they sent to know how the porter did, and heard upon enquiry, that the parent of the noses had been severely kicked the day before, and that the porter kept his bed on account of the bruises it had received. This was highly resented by the Spaniards, who found out the person that had used the porter so unmercifully, and treated him in the same manner as if the indignity had been done to their own noses. In this and several other cases it might be said, that the porters led the gentlemen by the nose. 
On the other hand, if anything went amiss with the nose, the porter felt the effects of it, insomuch that it was generally articled with the patient, that he should not only abstain from all his old courses, but should on no pretence whatsoever smell pepper, or eat mustard; on which occasion, the part where the incision had been made was seized with unspeakable twinges and prickings. (246)

'Sympathy', as described in this passage, may be both ridiculous and disturbing. Addison adeptly echoes the earnest language of philosophical-medical tracts on sympathy in his descriptions of "unspeakable twinges" and "eminent instances", thus highlighting the gap between the lofty speech of physician-authors and the bodily excreta with which they dealt. Furthermore, sympathy serves as an apt vehicle for the concern with grotesque bodies identified by Richard Braverman as characteristic of early eighteenth-century satire. After the seismic events of the civil war and regicide, followed by the Glorious Revolution, heredity and social order were clearly under threat - a threat which Braverman identifies as having lasted well beyond the Restoration and into the mid-eighteenth century (79). On the work of Swift and Pope (the former a close friend of Addison), Braverman writes:

As they saw it, theirs was a rearguard action against an invader that could not be turned back, and in resurrecting the grotesque body for satiric ends they recognized that the classical past could not be restored ... In its place came the grotesque body, which as the revolutionary threat from below gave vent to popular desire in politics and culture alike. (78)

Addison's vision of the body in 'Noses' is nothing if not grotesque, and the doctrine of sympathy realises the "threat from below" in more ways than one. The effects of sympathy make certain that we continue to see the join of even the most skilfully matched new nose; the join between different body parts, between different bodies, and between the face one deserves and that which one purchases. In such a climate, the body ceases to be a reliably 
readable text. Physiognomy and the noble body, already both fraught ideals, are further dismantled by the possibility of extreme corporeal self-fashioning. Seeing the join also means seeing the disjuncture between the desire for rationalism and politeness espoused by the middle and upper ranks of society, and the seedy sexual conduct of young men in those ranks. Writing on Addison and Steele's moral aims in the Spectator (established in 1711, one year after Addison's 'Essay'), Roy Porter asserts that

The Spectator created and publicized an eligible persona for the new, post-1688 public: man as a sociable being. This modern self rested upon a healthy and disciplined body. And that, in turn, would sustain a healthy mind, one which avoided ensnarement in phantasms and which, in the Lockean dispensation, would prove capable of continuous adaptation to the exigencies of a challenging but opportunityrich environment. Man thus became not just a sociable animal but a progressive one, too. (129)

In his Essay, Addison admonishes - though gently - against behaviour which is decidedly anti-social. Perhaps, however, he recognizes the irony of inveighing against false appearances. In writing satire, Addison affects an innocence he does not possess, telling a story which is not real, about an impossible operation. The possessors of Tagliacozzi's borrowed faces are not the only ones who deal in phantasms.

\section{Conclusion}

Too big, too small, long, short, deformed, false or entirely missing, early modern noses helped people to read one another's bodies. It was apt, therefore, that Addison should choose noses as the vehicle by which he interrogated just how such readings could work and whether they should work. As a primarily comedic work, 'Noses' participated in the long and dishonourable tradition of making fun of bodily difference, and of those who invested heavily in their appearance. However, it also highlighted the difficulties involved in knowing other 
people in a period in which judging by appearance was becoming more difficult. By 1710, physiognomy was waning as a popular science (though it would revive spectacularly in the late eighteenth century). Humoralism, which intimately connected bodily physiology with emotional wellbeing, remained in widespread use, but it was assailed by less holistic, iatrochemical theories. Most importantly for this reading, the class divisions with which generations of early modern people were familiar were, nominally at least, under threat. The Civil War had unleashed a threat from below which could not be readily contained despite the restoration of Charles II to the throne. In this climate, it was clear that the noble body was no longer the stable entity it had once appeared. Addison's gallants may attempt to cover up the real (and publicly hazardous) consequences of their misdeeds with a perfectly matched new nose. In the end, however, the sympathy between their new flesh and its original owner ensures that the remedy is never complete. Instead, they are debased by the grafting procedure and later forced to participate in the quarrels and misfortunes of those whose feelings they now (literally) share. It would be disingenuous to cast Addison as advocating for class breakdown. Indeed, Addison's satire has rightly been characterised as 'lightly admonitory', refraining from the vicious excesses of contemporaries such as Swift (Justman, 34). Nonetheless, by illuminating the tenuousness of the affiliation between inherent merit and external appearance, Addison may suggest a new way of being-in-the-body; one in which the precedence of blood gives way to a deliberate cultivation of the self.

\footnotetext{
${ }^{\mathrm{i}}$ See, for example, Danielle Westerhof, Death and the Noble Body in Medieval England; Thomas A. King, The Gendering of Men, 1600-1750; Mark Breitenberg, Anxious Masculinity in Early Modern England.

ii On this topic, see also Michael McKeon, The Origins of the English Novel 1600-1740 (Baltimore: Johns Hopkins University Press, 1987).
} 
iii "allograft, n.". OED Online. September 2015. Oxford University Press. www.oed.com (accessed September 10, 2015). 'A transplant (of tissue or an organ) between genetically dissimilar individuals of the same species; (also) transplantation of this kind.' "homoplastic, adj.". OED Online. June 2015. Oxford University Press. http://www.oed.com (accessed August 31, 2015). 'Of transplantation: involving the transfer of tissue from one individual to another of the same species. Of transplanted tissue: obtained from another individual of the same species as the recipient.'

${ }^{\text {iv }}$ On the commercial reappropriation of the doctrine of sympathy, see Francis Doherty's A Study in Eighteenth-century Advertising Methods: The Anodyne Necklace (1992), in which he discusses how retailers of the anodyne necklace drew directly from Addison's essay as supporting material for their defence of sympathetic medicines. 


\section{Works cited}

Addison, Joseph. 'Noses' The Tatler Issue 260 (December 7, 1710), (London: 1709 [1710]). Via Eighteenth Century Collections Online Text Creation Partnership, http://quod.lib.umich.edu (accessed September 14, 2015), pp. 243-8.

Allen, Charles (introduction by L. Lindsay). Curious Observations on the Teeth (London: John Bale, Sons \& Danielsson, Ltd, 1924 [London: 1687]).

Benedict, Barbara M. 'Reading Faces: Physiognomy and Epistemology in Late EighteenthCentury Sentimental Novels', Studies in Philology 92.3 (1995), pp. 311-318.

Berek, Peter. '"Looking Jewish" on the Early Modern Stage' in Jane Hwang Degenhardt and Elizabeth Williamson (eds.), Religion and Drama in Early Modern England: The Performance of Religion on the Renaissance Stage (Farnham; Burlington: Ashgate, 2011), pp. 55-70.

Boyle, Robert. 'Tryals proposed by Mr. Boyle to Dr. Lower, to be made by him, for the improvement of Transfusing Blood out of one live Animal into another' Philosophical Transactions 22 (February 11, 1666), pp. 385-9.

Braverman, Richard. 'Satiric Embodiments: Butler, Swift, Sterne' in James E. Gill, ed., Cutting Edges: Postmodern Critical Essays on Eighteenth-Century Satire (Knoxville: University of Tennessee Press, 1995), pp. 76-93.

Breitenberg, Mark. Anxious Masculinity in Early Modern England (Cambridge: Cambridge University Press, 1996).

Brewer, John. 'Sentiment and Sensibility' in James Chandler, ed. The Cambridge History of English Romantic Literature (Cambridge: Cambridge University Press, 2009), pp. 1944.

Cobb, Matthew. The Egg and Sperm Race: The Seventeenth-Century Scientists Who 
Unravelled the Secrets of Sex, Life and Growth (London: The Free Press, 2006).

Cock, Emily. "'Lead[ing] 'em by the Nose into Publick Shame and Derision": Gaspare Tagliacozzi, Alexander Read and the Lost History of Plastic Surgery, 1600-1800' Social History of Medicine, 28:1, pp. 1-21.

Cooke, James. Mellificium chirurgice, or, the marrow of many good authors enlarged (London: 1662).

Crawford, Patricia. 'Sexual Knowledge in England, 1500-1750' in Roy Porter and Mikulas Teich, eds., Sexual Knowledge, Sexual Science: The History of Attitudes to Sexuality (Cambridge: Cambridge University Press, 1994), pp. 82-106.

Digby, Sir Kenelm (trans. R. White). A Late Discourse, Made in a Solmne Assembly of Nobles and Learned Men at Montepellier in France: By Sr. Kenelme Digby, Knight, $\& c$. Touching the Cure of Wounds by the Powder of Sympathy; With Instructions how to make the said Powders; whereby many other Secrets of Nature are unfolded (London: 1658).

Doherty, Francis Cecil. A Study in Eighteenth-century Advertising Methods: The Anodyne Necklace (New York: Edwin Mellen Press, 1992)

Fisher, Will. Materializing Gender in Early Modern English Literature and Culture (Cambridge: Cambridge University Press, 2006).

Fludd, Robert. Doctor Fludds answer unto M. Foster or, The squeesing of Parson Fosters sponge, ordained by him for the wiping away of the weapon-salve Wherein the sponge-bearers immodest carriage and behaviour towards his bretheren is detected; the bitter flames of his slanderous reports, are by the sharpe vineger of Truth corrected and quite extinguished: and lastly, the verrtuous validity of his Sponge, in wiping away of the Weapon-Salve, is crushed out and cleane abolishd (London: 1631). 
Foster, William. Hoplocrisma Spongus: Or, A Sponge to Wipe Away the Weapon-Salve. A Treatise, wherein is proved, that the Cure late-taken up amongst us, by applying the Salve to the Weapon, is Magicall and unlawfull (London: 1631).

Gauden, John. A Discourse of Auxiliary Beauty. Or Artificiall Hansomnesse. In point of Conscience between Two Ladies (London: 1656).

Gnudi, Martha Teach, and Jerome Pierce Webster. The Life and Times of Gaspare Tagliacozzi, Surgeon of Bologna 1545-1599: With a Documented Study of the Scientific and Cultural Life of Bologna in the Sixteenth Century (New York: H. Reichner, 1950).

Guerrini, Anita. 'The Ethics of Animal Experimentation in Seventeenth-Century England' Journal of the History of Ideas, 50:3 (1989), pp. 391-407.

Hamilton, David. A History of Organ Transplantation: Ancient Legends to Modern Practice (Pittsburgh: University of Pittsburgh Press, 2012).

Helmont, Jean-Baptiste van ('translated, illustrated and ampliated' by Walter Charleston). $A$ Ternary of Paradoxes, second edition (London: 1650).

Justman, Stewart. The Springs of Liberty: The Satiric Tradition and Freedom of Speech (Evanston: Northwestern University Press, 1999).

Karim-Cooper, Farah. Cosmetics in Shakespearean and Renaissance Drama (Trowbridge: Edinburgh University Press, 2006).

Kerwin, William. Beyond the Body: The Boundaries of Medicine and English Renaissance Drama (Amherst: University of Massachusetts Press, 2005).

King, Thomas A. The Gendering of Men, 1600-1750. Vol. 1, 'The English Phallus' (2 vols.) (Madison: University of Wisconsin Press, 2004).

Lavater, Johan Caspar. Essays on Physiognomy, Designed to Promote the Knowledge and the 
Love of Mankind (London: printed for John Murray; H. Hunter; and T. Holloway, 1789).

Lobis, Seth. The Virtue of Sympathy: Magic, Philosophy and Literature in SeventeenthCentury England (New Haven; London: Yale University Press, 2015).

Mc Inerney, Timothy. 'The Better Sort: Nobility and Human Variety in Eighteenth-Century Great Britain' Journal for Eighteenth-Century Studies, 38:1 (2015), pp. 47-63.

McKeon, Michael. The Origins of the English Novel 1600-1740 (Baltimore: Johns Hopkins University Press, 1987).

Mullan, John. Sentiment and Sociability: The Language of Feeling in the Eighteenth Century (Oxford: Oxford University Press, 1990)

Nardizzi, Vin. 'The Wooden Matter of Human Bodies: Prosthesis and Stump in A Larum for London' in Jean E. Feerick and Vin Nardizzi, eds., The Indistinct Human in Renaissance Literature (Basingstoke: Palgrave Macmillan, 2012), pp. 119-36.

Nardizzi's reading is in turn indebted to that of David Wills's Prosthesis (Stanford: Stanford University Press, 1995).

Noble, Louise. Medicinal Cannibalism in Early Modern English Literature and Culture (New York: Palgrave Macmillan, 2011).

Paster, Gail Kern. The Body Embarrassed: Drama and the Disciplines of Shame in Early Modern England (Ithaca: Cornell University Press, 1993).

Porter, Martin. Windows of the Soul: physiognomy in European Culture 1470-1780 (New York: Oxford University Press, 2005).

Porter, Roy. Flesh in the Age of Reason: The Modern Foundations of Body and Soul (London: Allen Lane, 2003).

Rizzo, Betty. 'Decorums' in Linda E. Merians, ed. The Secret Malady: Venereal Disease in 
Eighteenth-Century Britain and France (Lexington: University Press of Kentucky, 1996), pp. 149-67.

Rosenthal, Angela. 'Raising Hair' Eighteenth-Century Studies, 38:1 (2004), pp. 1-16.

Shepard, Alexandra. Meanings of Manhood in Early Modern England (Oxford Studies in Social History) (New York: Oxford University Press, 2003).

Tagliacozzi, Gaspare (trans. Joan H. Thomas and with an introduction by Robert M.

Goldwyn). De Curtorum Chirurgia per Institionem (New York: Gryphon Edition, 1996 [Venice, 1597]).

Tagliacozzi, Gaspare (trans. by Martha Teach Gnudi and Jerome Webster). 'Letter to Hieronymus Mercurialis, February 10, 1586', in Martha Teach Gnudi and Jerome Pierce Webster, The Life and Times of Gaspare Tagliacozzi, Surgeon of Bologna 1545-1599: With a Documented Study of the Scientific and Cultural Life of Bologna in the Sixteenth Century (New York: H. Reichner, 1950), p. 139.

Tucker, Holly. Blood Work: A Tale of Medicine and Murder in the Scientific Revolution (New York: W.W. Norton \& Company, Inc., 2011).

Vauguion, M. de la. A compleat body of chirurgical operations, containing the whole practice of surgery (London: 1699).

Vicary, Thomas. The Surgion's Directorie (London: 1651).

Walker, Garthine. Crime, Gender and Social Order in Early Modern England (Cambridge: Cambridge University Press, 2003).

Westerhof, Danielle. Death and the Noble Body in Medieval England (Woodbridge: Boydell and Brewer, 2008). Cambridge University Press, 2003).

Whytt, Robert. Observations on the Nature, Causes, and Cure of Those Disorders Which 
Have Been Commonly Called Nervous, Hypochondriac, Or Hysteric: To Which Are Prefixed Some Remarks on the Sympathy of the Nerves (London: T. Becket, and P. Du Hondt, and J. Balfour, 1765).

Woodforde, John. The Strange Story of False Teeth (London: Routledge \& Kegan Paul Ltd., 1968).

Zimbardo, Rose A. 'Satiric Representations of Venereal Disease; The Restoration versus the Eighteenth-Century Model' in Linda E. Merians, ed., The Secret Malady: Venereal Disease in Eighteenth-Century Britain and France (Lexington, KY: University Press of Kentucky, 1996), pp. 183-95. 